\title{
PENTING PERAN PERAWAT DALAM PENINGKATAN KESELAMATAN PASIEN
}

\author{
suci nurliza siregar 191101023 \\ sucinurliza69@gmail.com
}

\section{Latar belakang}

Peran perawat dalam peningkatan keselamatan pasien adalah suatu sistem yang membuat asuhan pasien di rumah sakit menjadi lebih aman dan nyaman. Keselamatan pasien merupakan tanggung jawab semua pihak yang berkaitan dengan pemberi pelayanan kesehatan. Pasien safety menjadi prioritas utama dalam layanan kesehatan dan merupakan langkah kritis pertama untuk memperbaiki kualitas pelayanan serta berkaitan dengan mutu dan citra rumah sakit (Depkes, 2008). Perawat sebagai ujung tombak pemberi pelayanan kesehatan merupakan hal yang penting untuk dikaji dalam rangka mempertahankan dan meningkatkan mutu pelayanan kesehatan. Kinerja yang baik merupakan jembatan dalam menjawab kualitas pelayanan kesehatan yang diberikan terhadap pasien baik yang sakit maupun yang sehat (Murdyastuti, 2010). Perawat harus sadar akan perannya sehingga dapat secara aktif ikut berpartisipasi untuk mewujudkan keselamatan pasien. Hal ini juga tidak akan mencapai optimal jika hanya dengan kerja keras dari perawat saja, namun didukung dengan sarana prasarana, manajemen rumah sakit dan tenaga kesehatan lainnya (Bawelle, 2013). Joint Comission International (JCI) membagi beberapa sasaran keselamatan pasien yaitu komponen identifikasi pasien, komponen penggunaan komunikasi efektif, komponen pemakaian obat dengan kewaspadaan tinggi, komponen ketepatan lokasi operasi, prosedur dan dan pasien yang akan dibedah, komponen mengurangi resiko terinfeksi, komponen menilai resiko pasien jatuh (JCI, 2016).

\section{Tujuan}

Tujuan pentingnya peran perawat dalam
keselamatan pasien 
untuk mengetahui penerapan keselamatan pasien dirumah sakit

\section{Metode}

Metode dari pengumpulan data dan iformasi untuk mengetahui peran perawat dalam mengambil tindakan akan terhindar dari resiko yang merugi pasien atau pun perawat

\section{hasil}

Berdasarkan hasil pencarian menyatakan bahwa peran perawat dalam keselamatan pasien dirumah sakit sebagai pemberi pelayanan keperawatan, perawat mengikuti SOP keselamatan pasien dan menerapkan prinsip etik dalam melakukan pelayanan kesehatan di rumah sakit, dengan memberikan pendidikan edukasi kepada pasien dan keluarga tentang asuhan keperawatan ada menerapkan kinerja tim yang handal dalam memberikan pelayanan, menerapkan komunikasi yang efektif kepada pasien dan kekuarga, mendokumentasikan dengan benar asuhan keperawatan, dan melaporkan kejadian dalam item keselamatan pasien sesuai dengan standar operasional prosedur di Rumah Sakit.

\section{PEMBAHASAN}

perawat memiliki sejumlah peran di dalam menjalankan tugasnya sesuai dengan hak dan kewenangan yang dimiliki. Peran perawat yang utama adalah sebagai pelaksana, pengelola, pendidik dan peneliti. Enam sasaran keselamatan pasien (patient safety) rumah sakit menurut Permenkes No. 1691/Menkes/Per/VIII/2011 yaitu ketepatan dalam mengidentifikasi pasien; meningkatkan komunikasi yang efektif; peningkatan keamanan obat yang perlu diwaspadai; kepastian tepat lokasi, tepat prosedur, tepat pasien operasi; pengurangan risiko infeksi terkait pelayanan kesehatan; dan pengurangan risiko pasien jatuh (Depkes RI, 2011).

\section{Tingkat Pengetahuan Perawat}

Pengetahuan adalah fakta, keadaan atau kondisi tentang pengertian mencakup kombinasi dari kesadaran sederhana tentang fakta dan pemahaman tentang bagaimana fakta itu berkaitan satu sama lain (www.goegle.com/pengetahuan (Green,1980). Dalam kode etik keperawatan disebutkan bahwa perawat memiliki tanggung jawab agar senantiasa memelihara mutu pelayanan keperawatan yang tinggi disertai kejujuran profesional yang menerapkan pengetahuan serta 
ketrampilan keperawatan sesuai dengan kebutuhan klien. Dalam hubungannya dengan teman sejawat, perawat berkewajiban melindungi klien dari tenaga kesehatan yang memberikan pelayanan kesehatan secara tidak kompeten, tidak etis dan ilegal.

\section{Pengelolaan Keselamatan Pasien di Rumah Sakit}

Standar keselamatan pasien tersebut terdiri dari: Hak pasien. Mendidik pasien dan keluarga Keselamatan pasien dan kesinambungan pelayanan, Penggunaan metoda-metoda peningkatan kinerja untuk Melakukan evaluasi dan program peningkatan keselamatan Peran kepemimpinan dalam meningkatkan keselamatan pasien, Mendidik staf tentang keselamatan pasien, Komunikasi merupakan kunci bagi staf untuk mencapai keselamatan Pasien Sasaran keselamatan pasien terdiri dari: Ketepatan identifikasi pasien, Peningkatan Komunikasi yang Efektif, Peningkatan Keamanan Obat yang perlu diwaspadai (HIGH-ALERT), Kepastian tepat-lokasi, tepat-prosedur, tepat pasien operasiPengurangan Risiko Infeksi Terkait Pelayanan kesehatan $\mathrm{Hal}$ yang dapat menyebabkan kecelakaan pasien adalah: Kesalahan dalam mengidentifikasi pasien, Komunikasi yang tidak efektif, Penggunaan obat high alert yang tidak aman, Tidak tepat lokasi, prosedur, dan pasien operasi, Pencegahan risiko infeksi yang buruk, Pencegahan pasien jatuh yang buruk Keselamatan pasien rumah sakit adalah suatu sistem dimana rumah sakit membuat asuhan pasien lebih aman. Sistem tersebut meliputi penilaian risiko, identifikasi dan pengelolaan hal yang berhubungan dengan risiko pasien, pelaporan dan analisis insiden, kemampuan belajar dari insiden dan tindak lanjutnya serta implementasi solusi untuk meminimalkan timbulnya risiko. Sistem tersebut diharapkan dapat mencegah terjadinya cedera yang disebabkan oleh kesalahan akibat melaksanakan suatu tindakan atau tidak melakukan tindakan yang seharusnya dilakukan (Depkes R.I.,2006).

\section{Upaya Perawat Mengoptimalkan}

\section{Keselamatan Pasien}

Dalam keselamatan pasien terdapat 6 goals diantaranya identifikasi pasien, komunikasi efektif, peningkatan keamanan obat, peningkatan benar (lokasi, pasien, 
prosedur pembedahan), mengurangi resiko infeksi, serta pengurangan resiko jatuh.Penelitian ini menfokuskan pada tindakan keselamatan pasien di ruang perawatan yang berhubungan langsung dengan tindakan perawat salah satunya adalah penekanan perihal keselamatan pasien saat timbang terima. Berdasarkan hasil penelitian ini didapatkan bahwa dari 40 perawat yang mengoptimalkan keselamatan pasien sebanyak 33 perawat dan yang kurang mengoptimalkan keselamatan pasien sebanyak 7 perawat. Hasil uji satatistik chisquar diperoleh nila $\rho=0,005<\alpha=0,005$. Hal ini menunjukkan bahwa ada hubungan yang bermakna antara peran perawat dalam mengoktimalkan peran perawat $\mathrm{Hal}$ ini sejalan dengan penelitian yang dilakukan oleh Windyastuti (2018) tentang Hubungan Pelaksanaan Timbang Terima Dengan Keselamatan Pasien di Ruang Rawat Inap Kelas III RSI Agung Semarang didapatkan nilai $\rho=0,000<0,05$ menunjukan bahwa ada hubungan pelaksanaan timbang terima dengan upaya mengoptimalkan keselamatan pasien

Upaya Perawat Mengoptimalkan Keselamatan Pasien Dalam keselamatan pasien terdapat 6 goals diantaranya identifikasi pasien, komunikasi efektif, peningkatan keamanan obat, peningkatan benar (lokasi, pasien, prosedur pembedahan), mengurangi resiko infeksi, serta pengurangan resiko jatuh.Penelitian ini menfokuskan pada tindakan keselamatan pasien di ruang perawatan yang berhubungan langsung dengan tindakan perawat salah satunya adalah penekanan perihal keselamatan pasien saat timbang terima. Berdasarkan hasil penelitian ini didapatkan bahwa dari 40 perawat yang mengoptimalkan keselamatan pasien sebanyak 33 perawat dan yang kurang mengoptimalkan keselamatan pasien sebanyak 7 perawat. Hasil uji satatistik chisquar diperoleh nila $\rho=0,005<\alpha=0,005$. Hal ini menunjukkan bahwa ada hubungan yang bermakna antara peran perawat dalam mengoktimalkan keselamatan pasien. Hal ini sejalan dengan penelitian yang dilakukan oleh Windyastuti (2018) tentang Hubungan Pelaksanaan Timbang Terima Dengan Keselamatan Pasien di Ruang Rawat Inap Kelas III RSI Agung Semarang didapatkan nilai $\rho=0,000<0,05$ menunjukan bahwa ada hubungan pelaksanaan timbang terima dengan upaya mengoptimalkan keselamatan pasien.

\section{Kepatuhan perawat melaksanakan SOP resiko pasien jatuh}

Frekuensi perilaku kepatuhan perawat dalam melaksanakan SOP resiko pasien jatuh lebih besar frekuensi perawat yang tidak patuh sebanyak $81(60,4 \%)$ perawat dibandingkan dengan frekuensi perilaku kepatuhan perawat dalam melaksanakan SOP resiko pasien jatuh yang patuh sebanyak 53 (39,6\%) perawat. Kurang patuhnya perawat disebabkan karena masih 
kurangnya sosialisasi yang dilakukan pada perawat mengenai SOP resiko pasien jatuh, kemudian tidak tersedianya SOP mengenai resiko pasien jatuh di masing-masing unit rawat inap sehingga menyebabkan kurangnya pengetahuan perawat mengenai SOP resiko pasien jatuh. Disamping itu kurang patuhnya perawat dalam melaksanakan SOP resiko pasien jatuh karena kurangnya pengawasan oleh bagian keperawatan. Oleh sebab itu perlu adanya peningkatan program pelatihan atau sosialisasi khususnya mengenai pencegahan kejadian keselamatan pasien bagi tenaga keperawatan dan pelatihan mengenai mengasuh pasien yang beresiko jatuh sesuai SOP untuk. Selain itu perlu adanya pengawasan yang ketat sebagai langkah awal untuk mendisiplinkan perawat dalam kepatuhan perawat melaksanakan SOP resiko pasien jatuh dalam memberikan asuhan keperawatn pada setiap waktu dan kepada setiap pasien. Kelman menjelaskan bahwa perubahan sikap yang dilakukan dengan individu diawali dengan proses patuh, identifikasi adalah tahap terakhir berupa internalisasi.

\section{Peningkatkan keamanan terhadap obat yang perlu diwaspadai}

Dua partisipan mencirikan obat high alert adalah obat yang konsentrasinya tinggi sehingga dalam penggunaannya biasanya harus diencerkan terlebih dahulu, dalam pemberian melalui intravena biasanya diberikan melalui kateter IV ukuran 20. Dua partisipan juga mencontohkan obat yang termasuk high alert seperti $\mathrm{KCl}, \mathrm{MgSO} 4$, dan Dextrose 40. Pernyataan tersebut sesuai dengan panduan sasaran keselamatan pasien dari JCI (2008) yang menyatakan bahwa Obatobatan yang sering disebutkan dalam isu keselamatan pasien adalah pemberian elektrolit konsentrat secara tidak sengaja Dua partisipan menyatakan obat - obat high alert akan diberikan stiker khusus warna merah bertuliskan high alert, kemudian disimpan di dalam troli emergency, dan tidak disediakan di ruangan secara sembarangan. Hal ini telah sesuai dengan panduan sasaran keselamatan pasien dari JCI yang menyatakan bahwa elektrolit konsentrat tidak berada di unit pelayanan pasien kecuali jika dibutuhkan secara klinis.

\section{KESIMPULAN}

Penelitian ini menemukan bahwa perawat mempunyai peran penting dalam pencegahan resiko kecelakan terutama pada peran sebagai konsultan. Dalam pencegahan resiko kecelakan diharapkan perawat mempunyai pengetahuan dan sikap yang baik serta memperhatikan aspek seperti beban kerja, kondisi lingkungan serta interupsi yang terjadi. Penelitian ini menemukan bahwa peran peawar sanagt penting dalam keselamatan pasien pengetahuan dan sikap mempunyai hubungan yang signifikan dalam pencegahan resiko kecelakan.

\section{DAFTAR PUSTAKA}

Andi Mappanganro, Vifta Ekariani.(2019). HUBUNGAN PERAN PERAWAT DALAM 
TIMBANG TERIMA DENGAN UPAYA MENGOPTIMALKAN KESELAMATAN

PASIEN. Bina Generasi;Jurnal Kesehatan,11.(1).35-36.

Bawelle,S.C.(2013).Hubungan Pengetahuan Dan Sikap Perawat Dengan PelaksanaanKeselamatan Pasien (Patient Safety) Di Ruang Rawat Inap RSUD Liun Kendage Tahuna. EJournal Keperawatan.1,(10):1-7.

Cahyono, S.B.(2008). Membangun Budaya Keselamatan Pasien Dalam Praktik Kedokteran. Yogyakarta: Kanisius

Dewi,Mursidah.(2012).Pengaruh Pelatihan

Timbang Terima Pasien Terhadap Penerapan Keselamatan pasien Oleh Perawat Pelaksana Di RSUD Raden Mattaher Jambi. Jurnal Health \& Suport.5,(3):647:652.

Iriyanto Pagala.(2017). Perilaku Kepatuhan Perawat Melaksanakan SOP Terhadap

Kejadian Keselamatan Pasien di Rumah Sakit X Kendari. Magister Promosi Kesehatan

Universitas Diponegoro. 12. (1). 140142.

Isnaini Nur Mahya, Rofii Muhammad.2014. PENGALAMAN PERAWAT PELAKSANA
DALAM MENERAPKAN KESELAMATAN PASIEN. Program Studi IImu keperawatan,

Fakultas Kedokteran, Universitas Diponegoro. 2. (1). 30-37.

Novi Yulianti, dkk. 2019. Analisis Faktor yang Mempengaruhi Peran Perawat Dalam Pencegahan

Medication Error Diruang Rawat Inap Rumah Sakit Awal Bros Batam. Rumah Sakit

Awal Bros, Jl. Gajah Mada Kav. 1 Batam, 29444, Indonesia. 15 (2). 130-139.

Sry yulia.dkk. (2020). PENINGKATAN PEMAHAMAN PERAWAT

PELAKSANAAN DALAM PENERAPAN KESELAMATAN PASIEN MELALUI

PELATIHAN PASIEN. Fakultas ilmu keperawatan universitas Indonesia depok 1642

indonesia.15.(3).185-19.

Simamora, R. H. (2018). Buku ajar keselamatan pasien melalui timbang terima pasien

berbasis komunikasi efektif: SBAR. Medan: USUpress.

Simamora, R. H. (2020). Learning of Patient Identification in Patient Safety Programs

Through Clinical Preceptor Models. Medico Legal Update, 20(3), 553556. 
Ulva, Fadillah.(2017). Gambaran

Komunikasi Efektif Dalam Penerapan

Keselamatan Pasien (Studi Kasus

Rumah Sakit X Di Kota Padang. Jurna

Pembangunan Nagari.2,(1):95-102.

Yusuf, Muhammad.(2017).Penerapan

Patient Safety Di Ruang Rawat Inap

Rumah Sakit Umum Daerah

Dr.Zainoel Abidin.Jurnal Ilmu

Keperawatan.5,(1):85-88. 